\title{
Development of Personal Social Activity: Formation of Students 'Political Culture
}

\author{
Natalia P. Nikonova
}

\begin{abstract}
The problems of the formation of a political culture based on the development of a person's social activity, its translation into a socio-political one, which is a factor in the formation of students' political culture, are examined. The article is based on a study whose purpose is a comprehensive scientific and theoretical analysis of the political culture of modern students; revealing the features of its formation. The authors argue that political culture is a set of regulations and values that determine the participation of people in the political life of society, the formation of political culture, citizenship among young people is inextricably linked with the process of political socialization, which lays the foundation for basic knowledge, judgments and ideas of the individual about politics, power, the state.
\end{abstract}

Keywords : Social activity, social activity, socio-political activity, culture, political culture, personality, values, norms, factors, conditions.

\section{INTRODUCTION}

The political culture of young citizens reflects the nature and degree of political and civic development of a given individual and acts as the core of value in social culture. In this regard, the problem of forming a mechanism for an effective political and civic culture of youth has become, perhaps, one of the most pressing problems of modern society, as Russian youth enters into life in very difficult and uncertain conditions of political, social, economic and legal development.

Let us turn to the concept of "political culture". For the first time the phrase "political culture" was introduced into the scientific literature by the German scientist I. G. Herder in his work "Ideas for the Philosophy of the History of Mankind" (1784), in which he mentions the formation of the political culture of society and its carriers. In the future, especially in the late XIX - early XX centuries, this category was widely used in political studies by various scientific schools (Herder \& Mikhailova 1977). In the modern period, American political scientists G. Almond and S. Verba were among the first to address the problem of political culture in their studies, the concept of which became the leading one in the 1950s and 1960s. In the work "Civic Culture" they first introduced the concept of national political culture, and also presented a classification of political culture by type. However, they left unresolved a very important question about the boundaries of political culture, as well as its structure. Despite this, the concept of political culture formulated in the article The American political scientist G.

Revised Manuscript Received on September 22, 2019.

* Correspondence Author

Natalia P. Nikonova, Tyumen Industrial University, Russia
Almond, "Comparative Political Systems," is still considered the basic one, although the author limited political culture to the sphere of consciousness (Almond, 1997).

\section{METHODOLOGY}

The analysis of domestic scientific literature on the issues under study allows us to distinguish two approaches to understanding the phenomenon of political culture. Representatives of the first approach reduce political culture to public consciousness, and most often to one of its dimensions - ideology (Zh T Toshenko, FM Burlatsky, AA Galkin, VV Trushkov, AN Nekrasova, IB Orlov). Supporters of the second approach - V. A. Shchegortsev, O. V. Golovan, V. F. Penkov and others - believe that political culture is one of the elements of political activity, identifying it with creative activity that generates new values.

The article is based on a study whose purpose is a comprehensive scientific and theoretical analysis of the political culture of modern students; revealing the features of its formation.

\section{RESULTS}

Socio-political self-determination and self-realization of young citizens are formed in the context of the transformation of all spheres of society. We share the opinion of I.S. Kon, that a certain stage of development, social status, as well as social status and activities specific to a given age, determine, on the one hand, the ability to perform certain social roles, and on the other, the set of rights and obligations assigned to this age layer determines them self-awareness and level of claims. "Periodization of the life path always includes a normative and valuable moment indicating what tasks an individual must solve in order to timely and successfully move to the next phase of life and age category" (Cohn 1989).

It is important to note that the political, economic, social and worldview transformations taking place in the country cannot but have a predominant influence on the formation of the political and civic activity of the young person, as well as on its civil-law orientations. Thus, the specificity of the political culture of youth is determined by its most important characteristics - age, social, psychological, moral and ethical, physiological, biological, as well as the conditions for the development of society in which it is formed as a subject of political life. Political culture directly affects political behavior and the development of political processes.

The political culture of youth as a set of value orientations and established positions is presented in the following forms (Carmine, 2004): 


\section{Development of Personal Social Activity: Formation of Students 'Political Culture}

a) cognitive - young people lack knowledge about certain political actions, appeals, slogans, and they cannot fully give a correct assessment of the political idea;

b) effective - youth involvement in political events;

c) evaluation - when evaluation criteria require evaluation criteria (Duranov \& Shvachko, 2014).

In "Political Science" they single out the basic and basic values of political culture, as well as its components as values. The basic values include: power and attitude to it, political and ideological values and norms (freedom, democracy). The main ones are traditions, customs, feelings, norms, stereotypes of behavior and relationships. The component components of political culture as values include cognitive-emotional, normative-value, activity components.

The political culture of the individual is considered in science from different perspectives. First of all, from the standpoint of the socialization of the individual, and secondly, its adaptation to the socio-political conditions of the development of society; thirdly, inculturation, the individual's individual entry into the culture of socio-political relations; from the position of including the individual in the political life of society, which is associated with the development of socio-political activity. Often, political culture is analyzed from the standpoint of its value, which has direct access to the socialization of the individual.

Based on the research of A. S. Karmin, D. E. Pogorely, V. Yu. Fesenko, K. V. Filippov and others, the following should be attributed to political culture:

a) knowledge of the politics of power and other public structures, social communities, political parties;

b) an assessment approach to the political activities of power structures, determination of principles and criteria for their activities; political orientations, personality attitudes, character of emotional attitude towards them;

c) the presence and recognition of standards of political behavior and relations that dominate a given social community or society as a whole (Kvasha, 2015) ..

Political culture is public in nature. By its nature, it must reach the masses. It manifests itself in the process of interaction of the relevant political forces with society. Political culture is manifested in their relationships and behavior. Consequently, in order to influence the formation of the political culture of students, it is necessary to include it in activities that have a political orientation, in a culture of relations based on the development of, first of all, social and social activity.

In the "Newest Political Dictionary", political culture is seen as "a system of historically established, relatively stable values, attitudes, beliefs and symbols expressing them that serve to streamline political experience and regulate political behavior" (Kvasha, 2015) .. A holds the same position S. Carmin: "Political culture," he argues, "is a set of regulations and values that determine the participation of people in political life," which is expressed in the behavior of people (Carmin, 2004).

Consequently, political culture is a combination of regulations and values that determine the participation of people in the political life of society.

It is important to note that the formation of political culture and citizenship among young people is inextricably linked with the process of political socialization, which lays the foundations of basic knowledge, judgments and perceptions of the individual about politics, power, the state, etc.

The formation of political culture in the course of political socialization begins with the family, while the nature and reliability of the young man's understanding of various political phenomena and events is largely determined by the level of political culture of his parents and the prevailing political views and guidelines in the family. Further, this process continues in general education and higher educational institutions. At this time, the person is rapidly gaining new political knowledge due to his involvement in the study of social sciences in the humanities. Gradually, the young man shows a need to compare the knowledge gained in the classroom from textbooks, lectures, media, with real life. Thus, a critical approach arises in assessing the reliability of a word, news events, and information. Then comes the moment when a young citizen can independently analyze and systematize various kinds of political phenomena.

The next step in introducing a young citizen to political culture, and, consequently, a new stage in his political socialization, may be participation in certain political parties, organizations, movements, political processes, in the course of political self-education and other forms of activity. The success of the formation of the level of political culture of youth, in our opinion, depends on what political values are its priority, and under what circumstances the activities of agents and counterparties of political socialization are realized. As noted, the political culture of young citizens is characterized by their specific political interests, preferences and attitudes. The political interests of youth should be understood as those interests that are important in the political sphere and serve as a source, motivation, motive for political action. The recognition of interests takes place in the process of comparing the political status of young citizens with other groups or communities. Structurally, political interests include the attitude of young people to the totality of political relations in society, to power structures, the assessment of their activities and practical activities to realize their interests.

The most important condition for the formation of the political culture of people is their inclusion in the political process, interaction with political reality. Various spheres of public life interact with the political system; all of them, to one degree or another, participate in the formation of a political culture and influence the main directions of this process.

The following main ways of forming a political culture can be distinguished:

1) The activities of the state to determine patterns of political behavior, the formation and consolidation of national political symbols. Through the adoption of legislative acts, the parameters of political culture are determined accordingly.

2) Political, ideological, educational and organizational activities of public organizations and, above all, political parties. They lay the foundations of the political consciousness of citizens, their thinking and behavior. It is the activity of political parties that forms the attitude of citizens towards parties and party systems, 
electoral behavior, ideas about the place of parties in the political system of society, the relationship between parties and the state, etc.

3) The participation of the church in everyday political life and its production of the basic models of political thinking and behavior of citizens.

Thus, Protestantism, orienting citizens to work, obedience to the law, and an active life position, had a huge impact on the political culture of Western countries.

4) Information and communication activities of the media. Media can form the basic political and cultural values of citizens, stereotypes of political behavior, affecting the maximum number of people in the shortest time intervals. The media play a particularly important role in transitional periods of society.

5) The impact of business on political relations (in countries with market economies).

Competition, the search for compromise solutions to problems, etc., are transferred to the sphere of politics.

6) The transfer with greater or lesser changes in the principles, norms and models of the army to political life (in countries with a totalitarian, authoritarian regime of government). Among such principles it is necessary to note unity of command, teamwork, the restriction of democracy, orientation to the use of force, increased secrecy, etc.

7) Transfer of the principles of family relations to political life. They determine the cultural content of politics.

8) The educational and upbringing process in educational institutions, in the framework of which there is a detailed information about the political system and its norms. History, social sciences are the most important means of establishing patriotic values, justifying the existing political system, and educating a respectable, law-abiding, loyal citizen to the authorities (Khaikin, 2000).

Among the preferences of political interests and needs of young people, their main areas can be distinguished:

1) the creation of a stable political life of society for the implementation of their life plans (education, employment, creating a family, etc.);

2) the realization of the rights and freedoms of youth in combination with civic duties and responsibilities;

3) providing conditions for the implementation of an active political position;

4) the right to nominate youth political leaders in the highest structures of power;

5) ensuring the right to receive reliable information about political events, as well as the right to speak in the media outlining one's political positions and preferences;

6) the impact on the adopted state and political decisions, on the actions of political leaders;

7) the right to express one's political views in full accordance with the Constitution of the country, etc.

At the same time, the specifics of the formation of the political culture of youth is due to the destruction in the minds of Russian citizens of the values and ideology of the Soviet past and the insufficient level of patriotic and civic education of modern youth. A sharp decline in the activity on the formation of spiritual and moral values of the younger generation occurred due to the exacerbation of the crisis in the era of perestroika and subsequent democratic transformations in our country.
As a result, there are phenomena of deformation of moral feelings in the youth environment, the spread of the cult of material values, the predominance of pragmatic prudence and symbolic manifestation of love for the native land and the Fatherland, which negatively affects the spiritual and civic development of youth. At the same time, socially significant qualities such as responsibility, tolerance, legal awareness and patriotism are inculcated in the youth environment rather difficultly and not always purposefully.

Thus, Russian youth is quite practical. She appreciates material wealth, work, seeks to rely on herself in everything. The mentality features of modern Russian youth, which largely determine its restrained attitude to any ideology and politics as a whole, determine its specific choice, motivation for political preferences and electoral attitudes. Given the specificity and lability of the consciousness of young people, the instability of their political orientations, young people need to be politically educated so that they recognize the importance of their own position in society and their political strength. It seems important to highlight the trends in the formation of political culture and citizenship of Russian youth:

firstly, youth cannot spontaneously develop the necessary qualities of a political culture without the support of state authorities, as well as the constant influence and political education of agents of political socialization;

secondly, the formation of the political culture of Russian citizens, including the young generation, is associated with such political processes as: reform, post reform, modernization,

thirdly, the majority of young people strive to be outside politics, they are inactive in social activities and do not see themselves in civil society institutions.

In this regard, we note a number of basic activities aimed at improving the political and civic culture of youth in the context of the transformation of Russian society (Malik, 2009):

- organization of regional and interregional, all-Russian conferences on the problems of improving the legal and political education of citizens, especially the younger generation;

- Creation of an Internet portal on legal propaganda, training and education of citizens.

We believe that it is important to highlight the trends in the formation of political culture and citizenship of Russian youth:

firstly, youth cannot spontaneously develop the necessary qualities of a political culture without the support of state authorities, as well as the constant influence and political education of agents of political socialization;

secondly, the formation of the political culture of Russian citizens, including the young generation, is associated with such political processes as: reform, post reform, modernization,

thirdly, the majority of young people strive to be outside politics, they are inactive in social activities and do not see themselves in civil society institutions.

In relation to students, one should rather talk about the formation of socio-political activity, rather than political culture, given that they are not

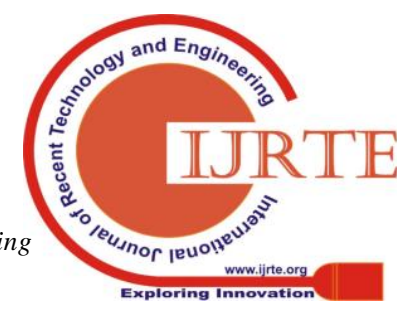




\section{Development of Personal Social Activity: Formation of Students 'Political Culture}

yet included in the active political life of society.

A retrospective look at the problem of the formation of the political culture of student youth shows that the study of humanitarian disciplines at a university should be systematic: firstly, in junior courses it is necessary to focus on the formation of social and civic activity; secondly, in subsequent courses, continuing to work, to focus on the development of social and socio-political activity. This creates the basis for the formation of the political culture of students, acting in the form of interconnected elements (social activity - civic activity - social activity - socio-political activity - political culture).

In terms of content, the study of humanitarian disciplines at a university should be focused on understanding the essence of political values, which in political science include: basic values (power and attitude to it), values-norms (freedom, democracy); basic values of the political culture of civil society (traditions, customs, feelings, norms, stereotypes of behavior and relationships).

In psychological and pedagogical terms, the formation of the political culture of students should be based on:

- on a component approach, including cognitive-emotional, normative-value, activity components;

- understanding the essence of political knowledge, acting in the form of values of political culture;

- the formation of attitudes, beliefs in the formation of political consciousness, responsible behavior, participation in political actions.

In the procedural and methodological plan, the formation of a political culture should be based on value orientations and a stage-level approach, where the first stage is subordinate to the students' orientation to social values associated with the socialization of a person; the second is connected with socialization, adaptation of a person to the system of values of political culture and inculturation; the third - with a focus on socio-political values, the formation of attitudes towards active socio-political activities.

We offer a number of basic activities aimed at improving the political and civic culture of youth in the context of the transformation of Russian society (Khaikin, 2000):

- organization of regional and interregional, all-Russian conferences on the problems of improving the legal and political education of citizens, especially the younger generation;

- Creation of an Internet portal on legal propaganda, training and education of citizens;

- organization and conduct of sociological research on

legal culture of youth and certain social groups;

- Creation of a "Legal Clinic" on the basis of universities;

- conducting an annual olympiad among schoolchildren, pupils and students on the best knowledge of federal and regional legislation, the rule-making base;

- holding an annual essay competition among schoolchildren and students

in various branches of political science, law, public administration;

- active involvement of the media and the QMS in the work on legal and political education of the region's population to organize legal consultations using the capabilities of the Internet, television, radio, newspapers and magazines.
It should be noted that the student population is the most active part of the population; therefore, the state is interested in its political socialization gaining a positive orientation.

The priorities of state interests and the whole society in relation to students should be the education and formation of a citizen who is actively involved in state and public life, in the functioning of social institutions based on legal norms, attitudes and values. In our opinion, it is high school education that is one of the important stages in the formation of the political and legal culture of a young citizen. At this time, the person is rapidly gaining new political knowledge due to his involvement in the study of social sciences in the humanities.

Gradually, the young man shows a need to compare the knowledge gained in the classroom from textbooks, lectures, abstracts, the media, with real life. This is a critical approach to assessing the credibility of a word and information. It should be recognized that "through the secondary institutions of socialization of youth, the national education system at all levels, the government bodies of youth affairs of special competence, power structures in terms of attracting young people to public service, political parties, public associations that have and are fulfilling the relevant statutory goals, are being implemented the main social (state) targeted impact on the process of socialization of youth, and therefore the implementation of that or another part of the state youth policy "(Malik, 2009).

Education is the most important factor contributing to the formation of personality; it is crucial for narrowing the cultural gap between different social strata, which ensures the unity and integrity of society. In improving the political culture of youth, it is not the formal level of education that is important, and not only knowledge as such. The leading role here is played by the moral and cultural aspects of the institution of education.

Work on the formation and improvement of the political and civic culture of youth should be carried out constantly, and be one of the priorities in building the educational and upbringing process. Then we will talk about building an integrated system of political education, legal education and upbringing of Russian youth in the spirit of citizenship and patriotism.

\section{CONCLUSION}

In conclusion, it should be emphasized that the transformations of social practices present new requirements for young citizens: they must be able not only to assert their rights, but also to fulfill their civil duties. It is in such conditions that young people should have the proper political and moral-value orientations, appropriate forms of civic behavior, a high level of political consciousness, political and legal socialization that contribute to the realization of social and professional expectations, aimed at legitimate forms of overcoming the crisis conditions of Russian society. Political education and the political culture of youth largely determine their ability and ability to exercise their civil rights. A politically cultured person is distinguished by clear-cut attitudes towards political institutions and structures, the normative system, individual political roles, and political leaders, taking into account their 
rating and authority. Such a person is characterized by a stable civil and moral position, tolerant orientation, restraint in behavior, intransigence to aggressive ignorance and extremism. The content and orientation of this process largely determine the further participation of the young generation in the transformations and improvement of the social system of Russia.

\section{REFERENCES}

1. Almond, G. (1997). Political science: the history of discipline. Policy. Political Studies, (6), 174-183.

2. Carmine, A.S. (2004). Culturology: Textbook. 5th ed. SPb .: Publishing house "Doe, 928

3. Cohn, I.S. (1989). Psychology of early youth: book. for teacher / Igor Semenovich Kon. M .: Education, 254.

4. Duranov, M.E., \& Shvachko, E.V. (2014). Theory and methodology of sociocultural education and personality development. Moscow: Humanity. ed. Center VLADOS

5. Herder, I. G., \& Mikhailova, A. V. (1977). Ideas for the philosophy of the history of mankind Text. In Monuments of historical thought / Acad. sciences of the USSR. M .: Science (p. 116).

6. Khaikin, V. L. (2000). Activity (characteristics and development). M .: Mosk. psychol. social in here.

7. Kvasha, A. (2015). Legal Power and Huge Suspension: Comparative Analysis of Categories. State control and self-determination, (1), 3-12.

8. Malik, E. N. (2009). Mass media as an institution of political socialization of youth in modern Russia.

9. Melnikov, A.V. (2014). Political participation of youth: actual problems of identifying value preferences. Central Russian Bulletin of Social Sciences, (3 (33)). 